\title{
DEVELOPMENT AND MORPHOMETRIC CHARACTERISTICS OF VETIVER GRASS UNDER DIFFERENT DOSES OF ORGANIC FERTILIZER ${ }^{1}$
}

\author{
FRANCISCO SANDRO RODRIGUES HOLANDA ${ }^{2}$, KAROLINE LOUISE LIMA DIAS DIAS ${ }^{2}$, \\ LUIZ DIEGO VIDAL SANTOS ${ }^{3 *}$, CHARLES RAMON DE MEDEIROS BRITO ${ }^{4}$, \\ JEANGELA CARLA RODRIGUES DE MELO ${ }^{2}$, LEANDRO SILVA SANTOS $^{2}$
}

\begin{abstract}
The use of organic fertilizers facilitates the production of plant species compared to industrial fertilizers, with a remarkable contribution to soil and water conservation through soil structuring. Vetiver grass (Chrysopogon zizanioides (L.) Roberty) is widely used in soil bioengineering projects to stabilize slopes, increasing the resistance of the soil to shear strength. The objective of this study was to evaluate the effect of the development of vetiver grass at different doses of organic fertilizer on soil stabilization. An experimental test was carried out in a greenhouse, in pots, using the following doses of organic fertilizer: T0-0 g (control); T1-135 g; T2-270 g and T3-405 g of organic fertilizer. Shoot Dry Matter (SDM), Root Dry Matter (RDM), Root Length (RL), Number of Tillers per Plant (NT) and Plant Height (PH) were evaluated. The collected data were submitted to regression analysis at $5 \%$ probability. The analysed variables showed increasing values as greater amounts of organic fertilizer, leading to an increase in soil nutrient availability and, consequently, to improved plant development.
\end{abstract}

Keywords: Chrysopogon zizanioides. Phosphorus. Soil bioengineering.

\section{DESENVOLVIMENTO E CARACTERÍSTICAS MORFOMÉTRICAS DO CAPIM VETIVER SUBMETIDAS A DIFERENTES NÍVEIS DE ADUBAÇÃO ORGÂNICA}

\begin{abstract}
RESUMO - Os usos de adubos orgânicos trazem benefícios na produção de espécies de plantas em comparação com os fertilizantes industriais, além de contribuir na conservação do solo e da água pela melhor estruturação do solo. O capim vetiver (Chrysopogon zizanioides (L.) Roberty), é amplamente utilizado em obras de bioengenharia de solos para a estabilização de encostas e taludes, aumentando a resistência do solo ao cisalhamento. O objetivo deste estudo foi avaliar o efeito do desenvolvimento do capim vetiver em diferentes doses de adubo orgânico para uso na estabilização do solo. Foi conduzido ensaio experimental em casa de vegetação, em vasos, e testadas as seguintes doses de adubo orgânico: T0- 0 g (controle); T1-135 g; T2- 270 g e T3- 405 g de adubo orgânico. Foram avaliadas as variáveis Matéria Seca da Parte Aérea (MSPA), Matéria Seca das Raízes (MSR), Comprimento de Raizes (CR), Números de Perfilhos por Planta (NPP), e Altura da Planta (AP). Os dados coletados foram submetidos a análise de regressão a $5 \%$ de probabilidade. As variáveis analisadas apresentaram valores crescentes à medida que foi disponibilizado maiores quantidades do adubo orgânico, que disponibilizou gradativamente nutrientes ao solo promovendo o melhor desenvolvimento da parte aérea pela maior disponibilidade de nitrogênio e assim potencializando maior cobertura ao solo.
\end{abstract}

Keywords: Chrysopogon zizanioides. Fósforo. Bioengenharia de solos.

\footnotetext{
${ }^{*}$ Corresponding author

${ }^{1}$ Received for publication in $05 / 13 / 2020$; accepted in 10/19/2020.

Paper of the Experimentation Research Group.

${ }^{2}$ Department of Agronomic Engineering, Universidade Federal de Sergipe, São Cristóvão, SE, Brazil; fholanda@infonet.com.br - ORCID: 0000-0001-6812-6679, k.vieira@outlook.com - ORCID: 0000-0001-9677-9802, jeangelamelo040@gmail.com - ORCID: 0000-0002-0293 -7011, leanderss@outlook.com-ORCID: 0000-0001-6347-907X.

${ }^{3}$ Universidade Federal de Sergipe, São Cristóvão, SE, Brazil; vidal.center@academico.ufs.br - ORCID: 0000-0001-8659-8557.

${ }^{4}$ Department of Agronomic Engineering, Universidade Federal Rural da Amazônia, Capitão Poço, PA, Brazil; charlescrmb@gmail.com ORCID: 0000-0003-0362-5455.
} 


\section{INTRODUCTION}

The remediation of degraded areas is a major challenge both in urban environments and to keep productive land in rural areas. However, physicochemical methods of soil remediation are generally expensive and result in a deterioration of the soil ecosystem. Thus, in recent years, new technologies, such as soil bioengineering, have been developed to stabilize and recover soils in a sustainable way (HOLANDA et al., 2009; ZAGO; DORES; WATTS, 2019). Biotechnics that use plant species in combination with inert materials for soil stabilization and protection against erosion can be used an alternative, as a complementary tool or even as a substitute for traditional civil engineering techniques (ARAÚJO-FILHO; HOLANDA; ANDRADE, 2013; MAFFRA; SUTILI, 2020).

Vetiver grass (Chrysopogon zizanioides (L.) Roberty), a native species from India, is a perennial plant from tropical and subtropical regions and belongs to the family Poaceae. It is widely known and used due to its high performance in ecological restoration programs, as well as its effectiveness in the control and prevention of erosive processes since it presents good resistance to shear stress (TRUONG; LOCH, 2004; NG et al, 2019; ETTBEB et al., 2020). The versatility of vetiver grass use has received much interest, with emphasis on its biotechnical characteristics for use in slope stabilization works, its contribution to the increase of soil cohesion and its high adaptability to various edaphoclimatic conditions (HOLANDA et al., 2012; ARAÚJO FILHO et al., 2015; MACHADO et al., 2015; COSTA et al., 2020).

Vetiver grass belongs to the superdivision Spermatophyta (which produces seeds) of the Magnoliophyta division (which produces flowers angiosperms), and of the order Poales (papyrus, bromeliad, pineapple, rush, 35 grasses). The family is Poaceae (grasses, including wheat, barley, rice and corn) and the genus Vetiveria, with the binomial name "Chrysopogon zizanioides (L.) Roberty" (LAL et al., 2018). It grows in clumps, as a perennial, herbaceous plant with stem-like stems (with long knots and internodes), reaching a height of up to $2 \mathrm{~m}$.

According to Miranda Neto (2015), the leaves, in their majority, are basilar (they appear just above the neck of the inflorescence), branched, conical, with numerous simple clusters and ears with small clusters of two tiny violet flowers and seeds. The rhizome is woody (i.e. hardened underground stem) and brownish, and the roots are yellow, fasciculated, flexible and intensely aromatic, reaching a depth of up to $4 \mathrm{~m}$.

The abundant root system of vetiver grass, contributing to increased shear resistance, is important to soil aggregation, necessary for the stabilization of hillslopes (BARBOSA; LIMA, 2013). Another important characteristic of vetiver is that it does not reproduce by seeds, preventing its free propagation (PRASAD et al., 2016).

Among its multiple uses, vetiver grass is used in the phytoremediation of wastewater and contaminated soils since it accumulates boron (XIN; HUANG, 2018). This species is also used in the recovery of contaminated soils with lead, as it absorbs and accumulates lead in its biomass. It is also adaptable to soil acidity and toxicity due to its efficient absorption of nutrients such as nitrogen and phosphorus (BAHRAMINIA et al., 2016). Vetiver grass can adapt to various soil conditions, an important requirement for its use in the recovery of degraded areas.

The intensive use of chemical fertilizers has been a common approach to improve yields in agriculture (WANG; YAO; YE, 2020). However, when effects of fertilizer use are observed in the interactions of the biota, as well as in the ecological and economic benefits, it is not always sustainable over time. Therefore, several alternative fertilization methods have been developed to maintain efficiency, maximum impact of the plant and minimum impact on the environment (LU et al., 2020).

In Brazil, the use of organic fertilizer has gradually increased mainly due to the high costs of industrialized fertilizers, as well as the availability of organic material from agro-industrial waste (PEREIRA, 2011). Organic fertilization is an agricultural practice widely used to improve the physical, chemical and biological properties of the soil. This type of fertilization is part of a production system committed to sustainable production, facilitating the preservation of the entire biota (VIEIRA et al., 2010). Organic fertilization proposes to use natural resources in a rational way, even employing traditional farming methods, but with the latest technologies (BENEDETTI; DALLABRIDA, 2016).

The use of organic fertilization in the cultivation of vetiver grass brings benefits such as the cyclical promotion of nutrients, mainly N, P and $\mathrm{K}$; the retention of cations, favouring plant growth in stress periods, results in increased productivity and in higher root development, which has been observed for other species of the Poaceae botanical family (SALLES et al., 2017; SEVERINO et al., 2006; SILVA et al., 2016).

Different organic compounds have been investigated regarding their role as organic phosphorus slow-release fertilizers (MAJEE; HALDER; MANDAL, 2019). Phosphorus is a macronutrient present in the soil and stimulating the growth of the absorption area of the root system, consequently stimulating plant growth (HOLANDA et al., 2017). Phosphorus deficiency in grasses such as vetiver causes a decrease in the transport of assimilates, which may negatively affect the photosynthetic rate, directly affecting the removal of carbon dioxide from the atmosphere (MIRANDA-

Rev. Caatinga, Mossoró, v. 34, n. 1, p. 20 - 30, jan. - mar., 2021 
VILLAGOMEZ et al., 2019), factors that can change the full performance of vetiver. In addition, Poaceae species respond well to increasing levels of phosphorus, which is of great importance for root development.

In comparison with industrial fertilizers, organic fertilizers can bring benefits such as improved soil quality (DONGGUANG et al., 2020), better soil aeration (WANG et al., 2018), reduced $\mathrm{N}_{2} \mathrm{O}$ release from manure (SHAH et al., 2020), increases in specific enzymes activities that capture $\mathrm{N}$ and P (LI et al., 2019), improved availability of soil nutrients and continuous compound release (ELFADIL et al., 2020). According to Santos Junior, Monteiro and Lavres Junior (2004), several factors are necessary for plant development, such as light, nutrients, and $\mathrm{CO}_{2}$. An increase in any of these factors, ranging from efficiency to sufficiency, promotes different rates of growth and production.

According to Tisdale and Nelson (2013) the increase in phosphorus solubility with the presence of organic matter results from the formation of phospho-humic complexes, which are assimilated by plants, causing anionic exchange of phosphate by the humate ion. The main factors affecting the

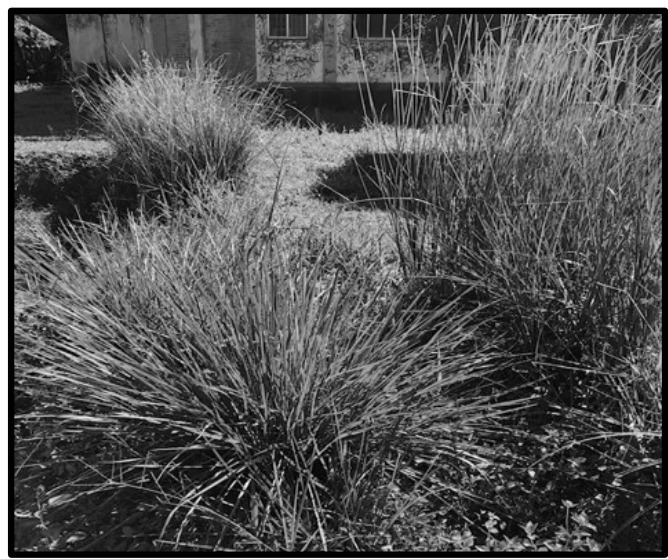

absorption of nutrients by plants are root growth rate, the concentration of $\mathrm{P}$ in the soil solution and root distribution and morphology, in addition to poor substrate application (DIAS et al., 2017; RAN et al., 2018; KULMANN, 2019).

In this context, the objective of this study was to evaluate the effect of the development of vetiver grass at different doses of organic fertilizer on soil stabilization.

\section{MATERIAL AND METHODS}

The experiment was conducted in a greenhouse with a temperature between 30 and $35^{\circ} \mathrm{C}$ from December to March, representing the summer season in Brazil. Tillers from a clump of vetiver grass growing in an experimental site at the University Campus of the Universidade Federal de Sergipe (UFS), located in the municipality of São Cristóvão, state of Sergipe $\left(11^{\circ} 01^{\prime} 53\right.$ "S, 37 $12^{\circ} 23^{\prime \prime}$ W), were used. Each tiller had a height of approximately $20 \mathrm{~cm}$, from clumps cultivated for 6 months (Figure 1).

Figure 1. Clumps of vetiver grass and tillers under development in the experimental test in a greenhouse.

We tested the following fertilizer doses: T0-0 $\mathrm{g}$ of organic fertilizer (control); T1-135 $\mathrm{g}$ of organic fertilizer (equivalent to $100 \mathrm{mg}$ of $\mathrm{P}_{2} \mathrm{O}_{5}$ ); T2-270 g of organic fertilizer $\left(200 \mathrm{mg}\right.$ of $\left.\mathrm{P}_{2} \mathrm{O}_{5}\right)$ and $\mathrm{T} 3-405 \mathrm{~g}$ of organic fertilizer ( $300 \mathrm{mg}$ of $\mathrm{P}_{2} \mathrm{O}_{5}$ ), per $\mathrm{kg}$ of soil, with three replicates for each treatment. The organic fertilizer was uniformly mixed with the soil in the pots, according to each treatment. Variations in fertilizer doses were made according to Araújo Filho et al. (2015), who observed the highest biomass production of vetiver grass at a dose of $300 \mathrm{mg}$ of $\mathrm{P}_{2} \mathrm{O}_{5} \mathrm{~kg}^{-1}$ soil. The used pots had a capacity of $2 \mathrm{~kg}$ and contained a mixture of $30 \%$ vermiculite and $70 \%$ washed and sieved sand, plus doses of organic fertilizer according to T0, T1, T2 and T3 treatments.

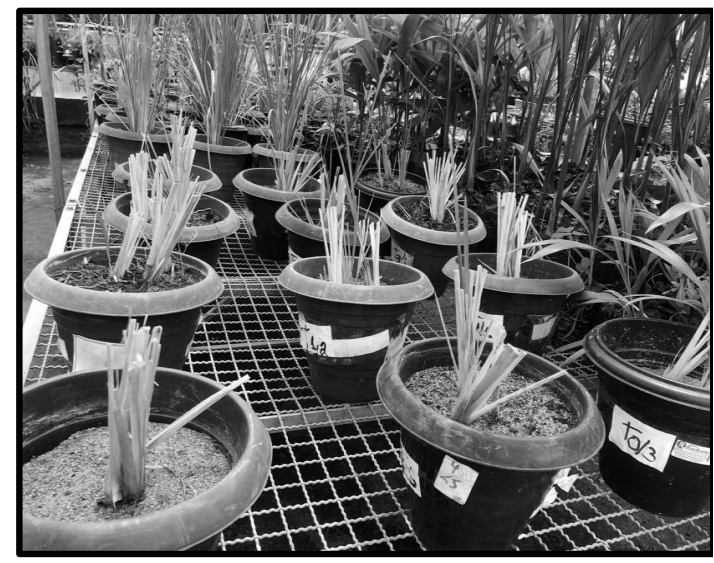


Table 1. Chemical parameters of the organic fertilizer Bioforte.

\begin{tabular}{lc}
\hline \multicolumn{1}{c}{ Parameters } \\
\hline $\mathrm{pH}$ CaCl 0.001 m & 6.5 \\
$\mathrm{~N}$ (Nitrogen) - $\mathrm{g} \mathrm{kg}^{-1}$ & 1.4 \\
$\mathrm{P}$ (Phosphorus) - $\mathrm{g} \mathrm{kg}^{-1}$ & 5.8 \\
$\mathrm{~K}$ (Potassium) - $\mathrm{g} \mathrm{kg}^{-1}$ & 10.8 \\
$\mathrm{Ca}$ (Calcium) - $\mathrm{g} \mathrm{kg}^{-1}$ & 37.4 \\
$\mathrm{Mg}$ (Magnesium) - $\mathrm{g} \mathrm{kg}^{-1}$ & 19.4 \\
$\mathrm{~S}$ (Sulphur) - $\mathrm{g} \mathrm{kg}^{-1}$ & 1.1 \\
$\mathrm{~B}$ (Boron) - $\mathrm{mg} \mathrm{kg}^{-1}$ & 11 \\
$\mathrm{Cu}$ (Copper) - $\mathrm{mg} \mathrm{kg}^{-1}$ & 29 \\
$\mathrm{Fe}$ (Iron) - mg kg-1 & 3.1 \\
$\mathrm{Mn}$ (Manganese) - mg kg-1 & 107 \\
$\mathrm{Zn}$ (Zinc) - $\mathrm{mg} \mathrm{kg}^{-1}$ & 479 \\
Organic carbon - $\mathrm{g} \mathrm{kg}^{-1}$ & 493.2 \\
$\mathrm{C}:$ N Ratio & $39: 1$ \\
\hline
\end{tabular}

The experimental period comprised the time from tiller planting and development up to 3 months, when tiller formation ceased and vegetative development peaked. After collecting the material (shoot and root system), the roots were separated from the soil by washing with a water jet, using 1.0$\mathrm{mm}$ mesh sieves, to minimize root loss (BÖHM, 1979). After washing, the roots were packed in paper bags and dried in an oven with forced air circulation at $65^{\circ} \mathrm{C}$ for 72 hours. The shoot biomass of the sampled individuals was also oven-dried at $65^{\circ} \mathrm{C}$ for $72 \mathrm{~h}$. Subsequently, roots and shoots were weighed on an analytical balance to determine Shoot Dry Matter (SDM) and Root Dry Matter (RDM). Root Length (RL) was determined with a ruler, in centimetres, from the neck to the apex of the root. The Number of Tillers per plant (NT) was determined considering the tillers emitted during the experimental period (3 months). Plant Height ( $\mathrm{PH})$ was measured considering the length from the plant's neck to the last node of the last released leaf.

The obtained values were analyzed using the software package SPSS (IBM Corp, 2017); regression analysis was performed at $5 \%$ probability.

\section{RESULTS AND DISCUSSION}

The tested stabilized residues showed an adequate $\mathrm{pH}$ for direct application to the soil, close to neutrality ( $\mathrm{pH}$ 6.5) (Table 1). When added to the soil, they probably regulate acidity due to the buffering capacity, neutralizing aluminium and stimulating the maintenance or formation of certain exchangeable bases, such as $\mathrm{Ca}, \mathrm{Mg}, \mathrm{K}$ and $\mathrm{Na}$, as stated by Müller (2012).

According to Padilha et al. (2014), factors such as temperature, humidity and soil aeration provide conditions for decomposition by increasing the biological activity in the soil. Considering that the soil moisture under the experimental conditions was always at field capacity, that the soil was highly porous (Entisol) and that the temperature in the greenhouse varied between 30 and $35^{\circ} \mathrm{C}$, the environment was favourable for microbial activity.

Based on the results of the regression analysis, the variables SDM, RDM, RL, NT and PH showed either quadratic or linear responses to different fertilizer doses.

According to Malavolta (2006), phosphorus from decomposition becomes available in organic form and is integrated into microbial cells; however, most of it remains readily available to plants. Sawyer et al. (2019) observed that at different P levels, the species Panicum virgatum L. (Poales) presented a similar growing behaviour for average biomass production, in comparison with unfertilised treatments, suggesting that the application of $\mathrm{P}$ is beneficial for plant establishment during the initial growth phase. We highlight the importance of $\mathrm{P}$ in root development, especially in Poaceae, and its role in increasing soil resistance and controlling soil erosion.

Considering that $\mathrm{N}$ mineralization requires higher water availability and that the soil was kept permanently at field capacity, we assume that throughout the experimental period of 3 months, mineralization was optimal, which is reflected in the high SDM values. Some authors stated that when applying organic fertilizers, $\mathrm{N}$ mineralization speed is generally reduced. Hangs, Ahmed and Schoenau (2016), working with organic fertilizers from waste, observed that the application of such fertilizers slowed down decomposition, resulting in the 
continuous supply of $\mathrm{N}$ for plant growth.

Figure 2 shows that SDM increases with increasing fertilizer doses, as reflected by the coefficient of determination $\left(\mathrm{R}^{2}=0.855\right)$. Pandit et al. (2020), working with corn (Zea mays L.), observed an increase in shoot dry matter in $243 \%$ when using higher doses of organic fertilizer in comparison with mineral NPK fertilizer. The increase in the Number of Tillers per plant (NT) with increasing doses of organic fertilizer also explains the increase in SDM (Figure 2).

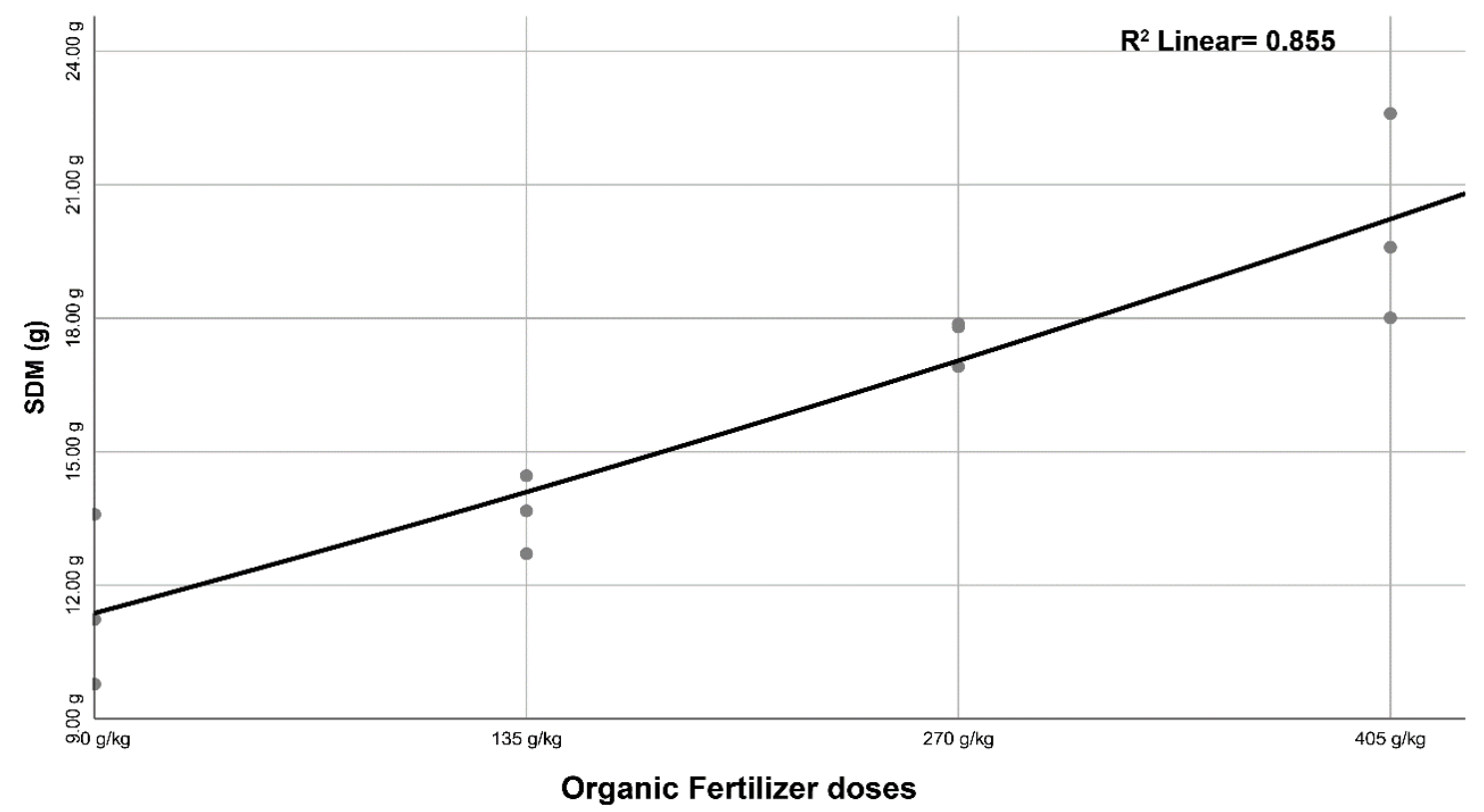

Figure 2. Shoot Dry Matter (SDM) of vetiver grass with different doses of organic fertilizer.

The increase in the Number of Tillers per plant (NT) (Figure 3), with increasing doses of organic fertilizer also explains the increase in SDM. The TN responded in a quadratic way $(\mathrm{P}<0.05)$ to the application of organic fertilizer, most likely associated with higher availability of $\mathrm{P}$ and $\mathrm{N}$ from microbial decomposition, which is in agreement with the results of Patês et al. (2007), working with Panicum maximum cv. Tanzania-1.

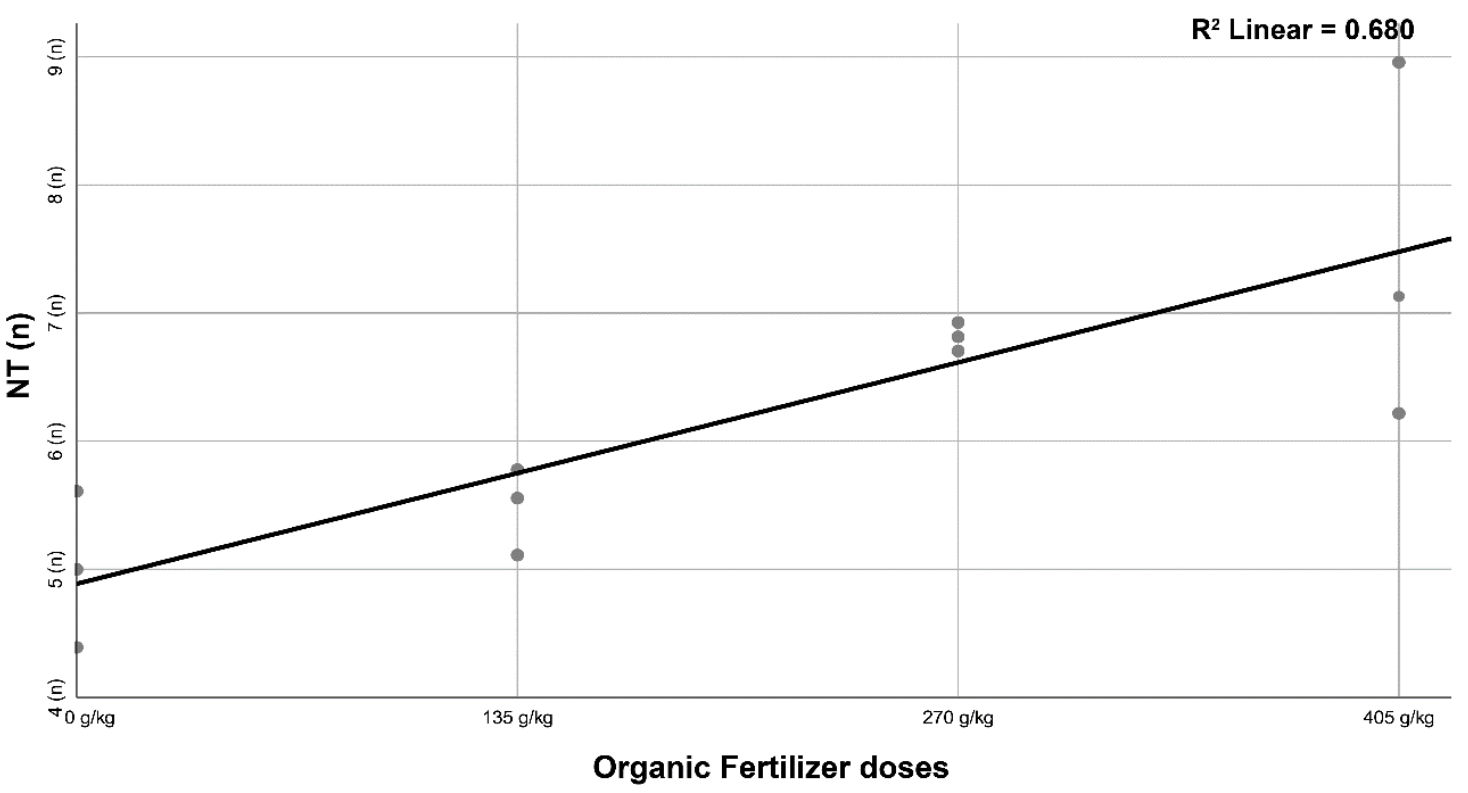

Figure 3. Number of Tillers per plant (NT) of vetiver grass at different doses of organic fertilizer. 
In the pots receiving $135 \mathrm{~g}$ of organic fertilizer per $\mathrm{kg}$ of soil, NT showed an increase of $42.85 \%$ in comparison with the control treatment (T0-Control), reaching increasing values, with the increase of doses, even though a better adjustment of the data related to the dose $270 \mathrm{~g}$ of organic fertilizer per $\mathrm{kg}$ of soil.

Figure 4 shows the differences in plant development due to the different doses of organic fertilizer. At 30 days after planting, tillers were present, although without panicles. In a previous study in Sergipe State, vetiver grass only presented inflorescence when subjected to strong temperature stresses, such as a long period with high temperatures (COSTA, 2015). Seed propagation (sexual) is considered difficult due to the low number of seeds produced (SIMAS, 2019). Therefore, this species generally uses vegetative propagation (asexual) by tillering. Only a few plants released panicles, making it impossible to assess this variable since there were no inflorescences in all tested treatments.

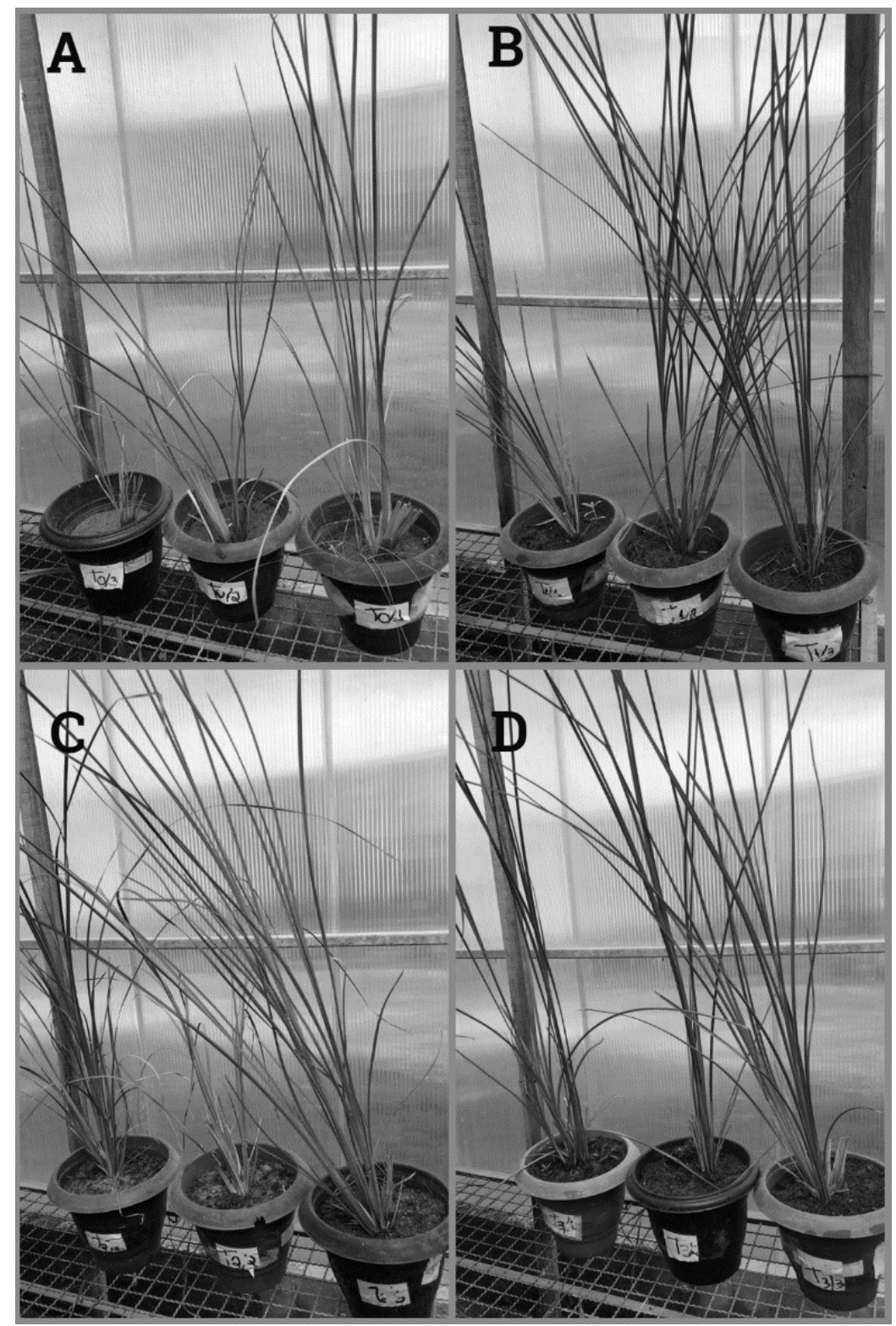

Figure 4. Plant development after 1 month of planting, showing T0-0 g of organic fertilizer (A); T1-135 g of organic fertilizer (B); T2-270 g of organic fertilizer (C) and T3-405 $\mathrm{g}$ of organic fertilizer (D).

The height of the plants has among the variables evaluated, the best fit of the curve $\left(\mathrm{R}^{2}=0.974\right)$ showing a linear regression in which the height of the plant increases as the doses of organic fertilizer increase (Figure 5). Majee, Halder and Mandal. (2019) observed the same behaviour in plant height growth when increasing doses of organic fertilizer were applied, most likely with highe concentrations of nitrogen, phosphorus and potassium available in the soil from organic materials. 


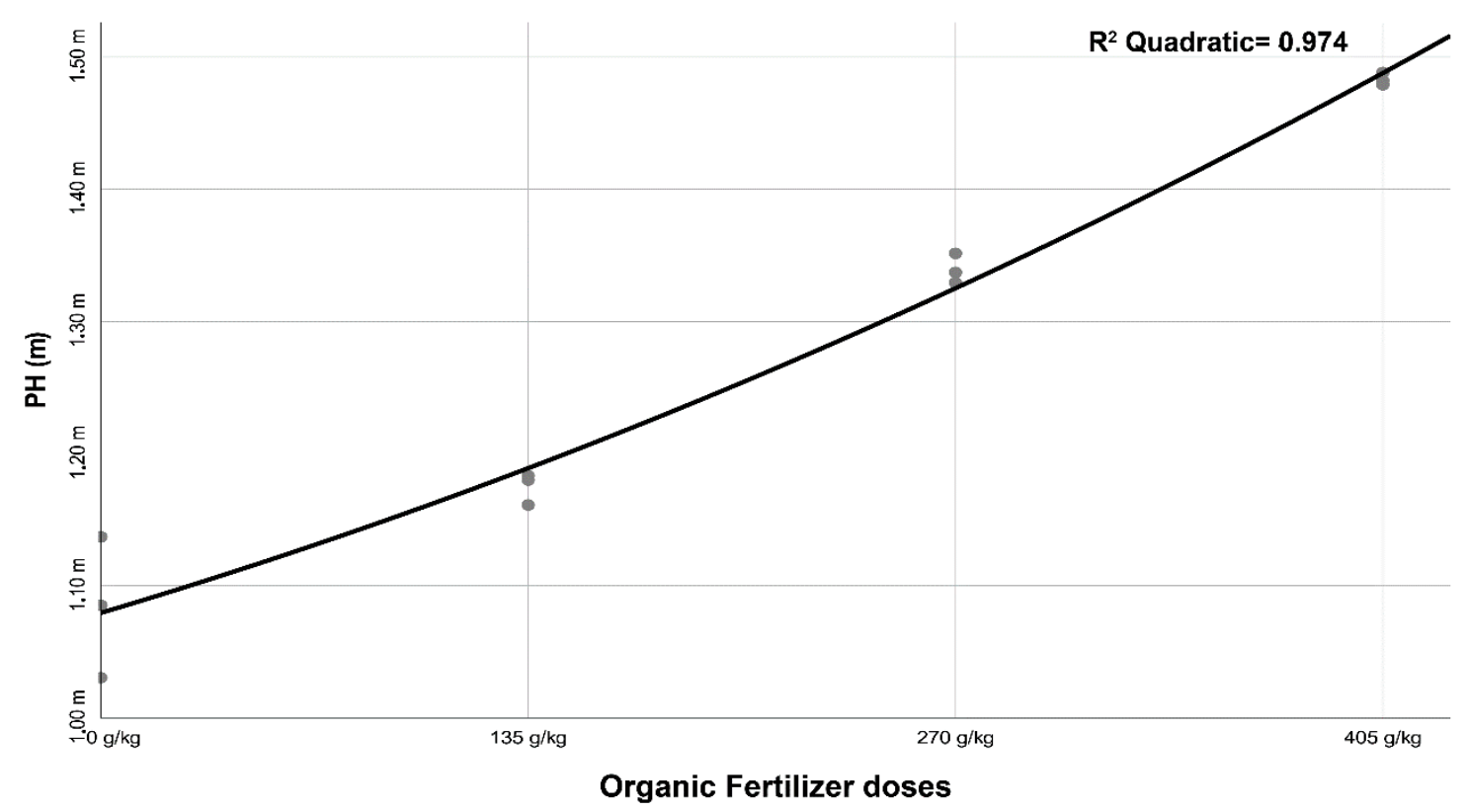

Figure 5. Plant Height $(\mathrm{PH})$ of vetiver grass at different doses of organic fertilizer.

The treatments with increasing doses of organic fertilizer (T1, T2 and T3) showed increased plant height when compared to the control treatment (T0). The T3 treatment (405 g of organic fertilizer per $\mathrm{kg}$ of soil) reached a maximum height of $1.45 \mathrm{~m}$. Vetiver grass responds positively to increased $\mathrm{P}$ levels, which, according to Teixeira et al. (2015) and Araújo Filho et al. (2015), also positively influences tiller number.

A quadratic trend was observed $\left(\mathrm{R}^{2}=0.034\right)$
(Figure 6) although very fragile adjustment related to RDM data, although it seems that a slight increasing levels were observed, related to $\mathrm{T} 2$ treatment.

Considering the experimental period, nitrogen was most likely available to vetiver grass after 60 days, when the plants showed greater vegetative vigour. Similarly, Souto et al. (2005) noted that in the first 30 days, vegetative vigour was decreased, influencing the amount of nutrients available at the beginning of plant development.

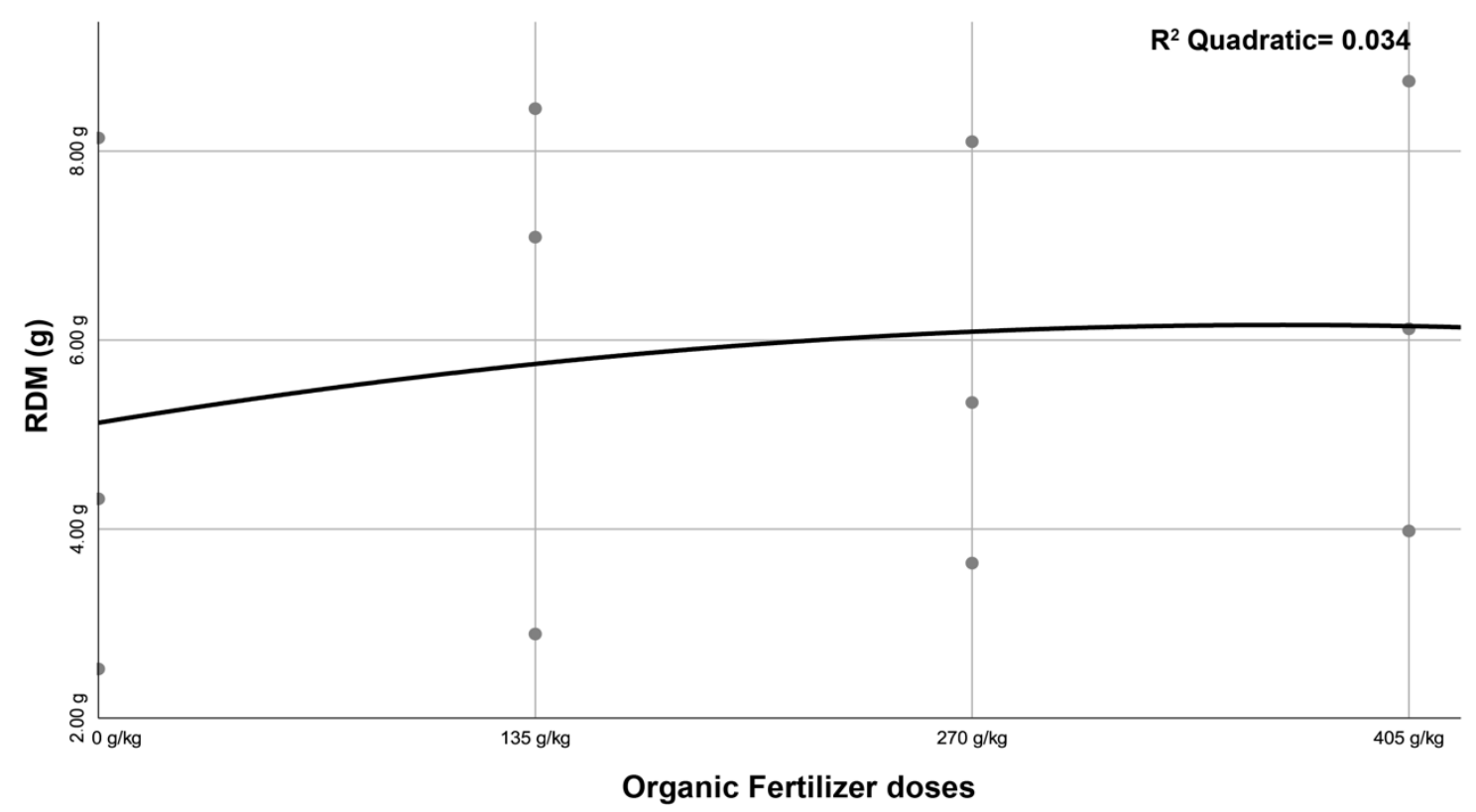

Figure 6. Root Dry Matter (RDM) of vetiver grass at different doses of organic fertilizer. 
When comparing SDM with RDM (Figure 6), SDM (Figure 7) showed a different behaviour, although RL increased with increasing fertilizer doses. The improved SDM can be explained by an increased $\mathrm{N}$ availability, since $\mathrm{C} 3$ plants in general present excellent responses to nitrogen.

With increasing availability of organic fertilizer, root growth was promoted (Figure 7), indicating that the nutrient absorption capacity is related to the root length, in addition to the phosphorus absorption kinetics, predominantly by diffusion, under favourable soil conditions, as $\mathrm{P}$ shows low mobility in soil. Under favourable soil conditions with a higher $\mathrm{pH}$, as was observed in the experimental condition, an unfavourable environment is established for phosphorus fixation in the soil, increasing its availability to plants and consequently bringing positive conditions to root development.

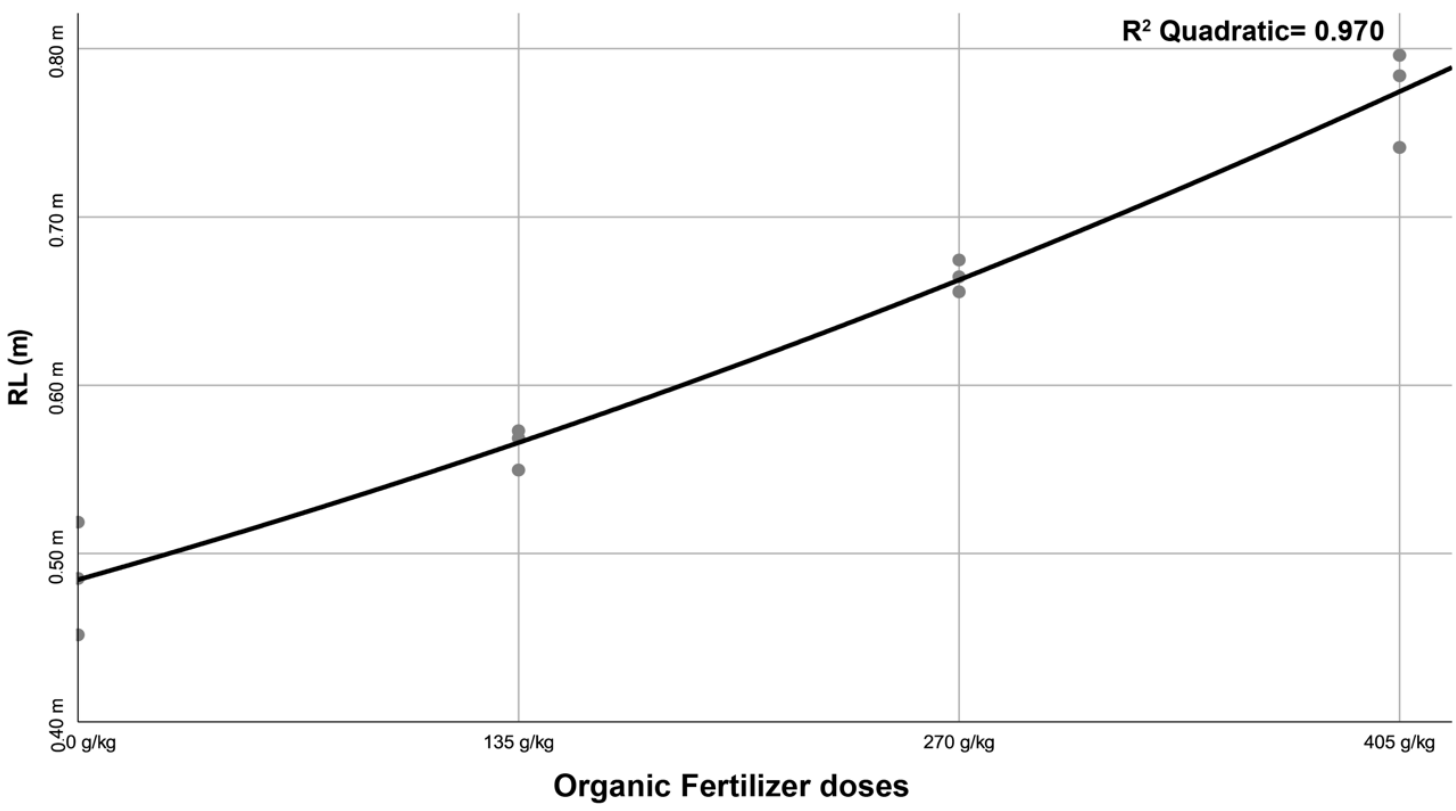

Figure 7. Root Length (RL) of vetiver grass at different doses of $\mathrm{P}_{2} \mathrm{O}_{5}$.

\section{CONCLUSIONS}

Vetiver grass subjected to increasing doses of organic fertilizer responded positively in terms of morphometric variables.

Shoot dry matter, number of tillers, plant height and root length increased with increasing doses of organic fertilizer, and this might have been a result of increased mineralisation, leading to greater $\mathrm{N}$ availability and, consequently, improved plant growth.

Increased plant development represented by SDM and RDM variables, results in better cohesion due to a better soil cover and greater root development, increasing soil resistance and avoiding soil runoff; these factors are important to guarantee a better soil erosion control.

\section{ACKNOWLEDGMENTS}

The authors thank the Centro de Empreendedorismo da Amazônia for allowing the development of the organic fertilizer ${ }^{\circledR B i o f o r t e, ~ a s ~}$ an entrepreneurial action of the Amazonia UP Program with young entrepreneurial academics in the State of Pará, Northern region, in tha Brazilian Amazon.

\section{REFERENCES}

ARAÚJO FILHO, R. N. et al. Efficiency of Simple Super Phosphate in the vetiver grass development subjected to soil bioengineering. Revista Caatinga, 28: 1-9, 2015.

ARAÚJO-FILHO, R. N.; HOLANDA, F. S. R.; ANDRADE, K. R. Implantação de técnicas de bioengenharia de solos no controle da erosão no baixo São Francisco, estado de Sergipe. Scientia plena, 9: 2-9, 2013.

BAHRAMINIA, M. et al. Effectiveness of arbuscular mycorrhizal fungi in phytoremediation of lead- contaminated soil by vetiver grass. International Journal of Phytoremediation, 18: 730-737: 2016. 
BARBOSA, M. C. R.; LIMA, H. M. Resistência ao cisalhamento de solos e taludes vegetados com capim vetiver. Revista Brasileira de Ciência do Solo, 37: 113-120, 2013.

BENEDETTI, E. L.; DALLABRIDA, V. R. Aspectos da multifuncionalidade no Planalto Norte Catarinense: adubação orgânica no incremente da produção de erva-mate. DRd - Desenvolvimento Regional em debate, 6: 147-169, 2016.

BÖHM, W. Methods of studying root systems. Springer, Heidelberg, 1979. 188 p.

COSTA, É. C. Efeito alelopático de Capim-vetiver (Chrysopogon zizanioides (L.) Roberty) e Capimpaspalum (Paspalum milegrana Schrad) provenientes de taludes da margem do Rio São Francisco. 2015. 88 f. Dissertação (Pós-Graduação em Agricultura e Biodiversidade) - Universidade Federal de Sergipe, São Cristóvão, SE, 2015.

COSTA, E. C. et al. Potencial alopático do Chrysopogon zizanioides e Paspalum millegrana na germinação de alface. Iheringia. Série Botânica, 75: e2020002-e2020018, 2020.

DIAS, L. P. R. et al. Distribuição e morfologia do sistema radicular de Eucalyptus dunnii em resposta à aplicação de fósforo. Revista de Ciências Agroveterinárias, 16: 203-213, 2017.

DONGGUANG, $Z$. et al. Experiment and optimization of sub-soil liquid fertilizer injection device. Ransações da Sociedade Chinesa de Engenharia Agrícola, 36: 31-39, 2020.

ELFADIL, S. et al. The effect of phosphate flotation wastes and phosphogypsum on cattle manure compost quality and plant growth. Journal of Material Cycles and Waste Management, 22: 9961005, 2020.

ETTBEB, A. E. et al. Root Tensile Resistance of Selected Pennisetum Species and Shear Strength of Root-Permeated Soil. Applied and Environmental Soil Science, 20: 100-110, 2020.

HANGS, R. D.; AHMED, H. P.; SCHOENAU, J. J. Influence of willow biochar amendment on soil nitrogen availability and greenhouse gas production in two fertilized temperate prairie soils. Bioenergy Research, 9: 157-171, 2016.

HOLANDA, F. S. et al. Comparison of different containers in the production of seedlings of vetiver grass for erosion control. Revista Brasileira de Ciências Agrárias, 7: 440-445, 2012.

HOLANDA, F. S. R. et al. Controle da erosão em margens de cursos d'água: das soluções empíricas à técnica da bioengenharia de solos. Ra'ega O Espaço Geográfico em Análise, 17: 93-101, 2009.

HOLANDA, F. S. R. et al. Biotechnical potential of Paspalum submitted to simple superphosphate doses and moisture content. Scientia Agraria, 18: 43-49, 2017.

IBM CORP, R. 2017. IBM SPSS Statistics for Macintosh, Version 25.0. Armonk, NY: IBM, 2017.

KULMANN, M. S. S. Eficiência de absorção de nitrogênio e dinâmica do crescimento do sistema radicular de Vitis vinifera e Eucalyptus sp. submetidos à adubação nitrogenada. 2019. $184 \mathrm{f}$. Dissertação (Mestrado em Ciência do Solo) Universidade Federal de Santa Maria-UFSM, Santa Maria, 2019.

LAL, R. K. et al. Phenotypic stability, genotype $\times$ environmental interactions, and cultivar recommendations for essential oil yield in khus aromatic grass (Chrysopogon zizanioides (L.) Roberty). Industrial crops and products, 111: 871 $877,2018$.

LI, Y. et al. Soil microbial community composition closely associates with specific enzyme activities and soil carbon chemistry in a long-term nitrogen fertilized grassland. Science of The Total Environment, 654: 264-274, 2019.

LU, J. et al. Rhizosphere priming effects of Lolium perenne and Trifolium repens depend on phosphorus fertilization and biological nitrogen fixation. Soil Biology and Biochemistry, 150: 108-128, 2020.

MACHADO, L. et al. Contribution of the root system of vetiver grass towards slope stabilization of the São Francisco River. Semina:Ciencias Agrarias, 36: 2453-2463, 2015.

MAFFRA, C. R. B.; SUTILI, F. J. The use of soil bioengineering to overcome erosion problems in a pipeline river crossing in South America. Innovative Infrastructure Solutions, 5: 24-18, 2020.

MAJEE, S.; HALDER, G.; MANDAL, T. Formulating nitrogen-phosphorous-potassium enriched organic manure from solid waste: A novel approach of waste valorization. Process Safety and Environmental Protection, 132: 160-168, 2019.

MALAVOLTA, E. Manual de nutrição mineral de plantas. 1 ed. Ouro Fino - MG: Agronômica Ceres, 2006. 638 p.

MIRANDA NETO, M. I. Contribuição das raízes da gramínea vetiver na resistência ao 
cisalhamento de um solo arenoso. Rio de Janeiro, RJ: Universidade Federal de Rio de Janeiro, 2015.

MIRANDA-VILLAGÓMEZ, E. et al. Nanophosphorus Fertilizer Stimulates Growth and Photosynthetic Activity and Improves P Status in Rice. Journal of Nanomaterials, 19: 27-38, 2019.

MÜlleR, D. H. Características de adubos orgânicos, efeitos no solo e no desempenho da bananeira. 2012. 83 f. Dissertação (Mestrado em Agricultura Tropical) - Universidade Federal de Mato Grosso, Faculdade de Agronomia, Medicina Veterinária e Zootecnia, Cuiabá, 2012.

NG, C. C. et al. Phytoassessment of Vetiver grass enhanced with EDTA soil amendment grown in single and mixed heavy metal-contaminated soil. Environmental Monitoring and Assessment, 191: e434, 2019.

PADILHA, K. M. et al. Indicadores biológicos de dois solos com a incorporação de subproduto da agroindústria de café. Revista Brasileira de Ciência do Solo, 38: 1377-1386, 2014.

PANDIT, N. R. et al. Nutrient effect of various composting methods with and without biochar on soil fertility and maize growth. Archives of Agronomy and Soil Science, 66: 250-265, 2020.

PATÊS, N. M. S. et al. Características morfogênicas e estruturais do capim-tanzânia submetido a doses de fósforo e nitrogênio. Revista Brasileira de Zootecnia, 36: 1736-1741, 2007.

PEREIRA, D. C. Decomposition and nutrient mineralization of organic fertilizers into porous capsules. 2011. 115 f. Dissertação (Mestrado em Engenharia Agrícola) - Universidade Estadual do Oeste do Paraná, Cascavel, 2011.

PRASAD, M. N. V. et al. Mulberry and Vetiver for Phytostabilization of Mine Overburden: Cogeneration of Economic Products. Bioremediation and Bioeconomy, 1: 295-328, 2016.

RAN, Y. et al. Identification of factors affecting rice yield gap in southwest China: An experimental study. PloS one, 13, e0206479, 2018.

SALLES, J. S. et al. Resposta da rúcula à adubação orgânica com diferentes compostos orgânicos. Journal of Neotropical Agriculture, 4: 35-40, 30, 2017.

SANTOS JUNIOR, J. D. G.; MONTEIRO, F. A.; LAVRES JUNIOR, J. Análise de crescimento do capim-marandu submetido a doses de nitrogênio.
Revista Brasileira de Zootecnia, 33: 1985-1991, 2004 .

SAWYER, A. et al. Cultivar and phosphorus effects on switchgrass yield and rhizosphere microbial diversity. Applied Microbiology and Biotechnology, 103: 1973-1987, 2019.

SEVERINO, L. S. et al. Produtividade e crescimento da mamoneira em resposta à adubação orgânica e mineral. Pesquisa Agropecuária Brasileira, 41:879 $-882,2006$.

SILVA, C. C. et al. Eficiência de utilização de adubação orgânica em forrageiras tropicais. Journal of Neotropical Agriculture, 3:48-54, 2016.

SHAH, S. H. H. et al. Optimizing farmyard manure and cattle slurry applications for intensively managed grasslands based on UK-DNDC model simulations. Science of The Total Environment, 714: e-136672, 2020.

SIMAS, B. et al. Desafios da propagação sexuada do umbuzeiro, spondias tuberosa Arr (Anacardiaceae). Inteletto, 4: 1-10, 2019.

SOUTO, P. C. et al. Decomposição de estercos dispostos em diferentes profundidades em área degradada no semi-árido da Paraíba. Revista Brasileira de Ciência do Solo, 29: 125-130, 2005.

TEIXEIRA, P. C. et al. Resposta de vetiver à aplicação de calcário e fósforo em três classes de solo. Revista Brasileira de Engenharia Agrícola e Ambiental, 19: 99-105, 2015.

TISDALE, S. L.; NELSON, W. L. Soil Fertility and Fertilizers. 4 ed. Soil Science, 2013. 346 p.

TRUONG, P.; LOCH, R. Vetiver system for erosion and sediment control. In: ISCO $13^{\mathrm{a}}$., Brisbane: International Soil Conservation Organisation Conference, 13., 2004. Brisbane. Anais... 2004. p. 1-10.

VIEIRA, P. F. Do preservacionismo ao desenvolvimento territorial sustentável. Política \& Sociedade, 8: 27-78, 2010.

WANG, S.; YAO, X.; YE, S. Soil aggregate-related organic carbon and relevant enzyme activities as affected by tea (Camellia sinensis L.) planting age in hilly region of southern Guangxi, China. Applied Soil Ecology, 150: 103-444, 2020.

WANG, H. et al. Variation of Organic Matter Decomposition in Constructed Wetlands with Enhancing Aeration. Nature Environment and Pollution Technology, 17: 507-510, 2018. 
XIN, J.; HUANG, B. Comparison of boron uptake and translocation in two vetiver genotypes and evaluation of boron removal efficiency of vetiver floating islands. International Journal of Phytoremediation, 20: 847-854, 2018.

ZAGO, V. C. P.; DORES, N. C.; WATTS, B. A. Strategy for phytomanagement in an area affected by iron ore dam rupture: A study case in Minas Gerais State, Brazil. Environmental Pollution, 249: 10291037, 2019. 